\title{
Soil recovery following landslides at Whatawhata Research Station, Waikato, New Zealand: preliminary results
}

\author{
A.M. NOYES, M.R. BALKS, V.G. MOON and D.J. LOWE \\ School of Science, University of Waikato, Private Bag 3105, Hamilton 3240, New Zealand \\ adrea@slingshot.co.nz
}

\begin{abstract}
This research investigates soil recovery following landslides at the Whatawhata Research Station $20 \mathrm{~km}$ west of Hamilton. Six landslides were studied, ranging in age from pre-1953 to 2014. The landslides were divided into four zones: shear zones (mean of $25 \%$ of landslide area), intact accumulation zones (20\%), transition zones $(40 \%)$, and re-deposition zones $(15 \%)$, along with a control. Soils were well-developed in the control and intact accumulation zones and least recovered in the shear and re-deposition zones. Mean A horizon depths ranged from $2 \mathrm{~cm}$ in the shear and re-deposition zones to $7 \mathrm{~cm}$ in the transition zone, $17 \mathrm{~cm}$ in the intact accumulation zone, and $20 \mathrm{~cm}$ in the control. Mean soil carbon contents were lower $(\mathrm{P}<0.05)$ in the landslide zones (range of 3.2-5.2\%) than in controls $(8.2 \%)$. Older landslides showed greater recovery, however, the differences between zones within the landslides were greater than the differences between landslides.
\end{abstract}

Keywords: mass movement, soil carbon, hill country

\section{Key statements}

- Four geomorphic zones were identified within landslides

- Soil recovery varied more between zones than between landslides of different ages

- The least recovered shear zones comprised less than $25 \%$ of the landslide area.

\section{Introduction}

More than $40 \%$ of New Zealand is moderately to very steep, forming extensive hill country $\left(21-25^{\circ}\right)$ and steeplands $\left(>26^{\circ}\right)$ (Leathwick et al. 2003). Such landforms are prone to slope failure resulting in landslides, particularly during periods of high rainfall which often triggers earth movement (Crozier 2005; De Rose 2013). Landsliding (mass movement) results in soil materials and nutrients being transported downslope leaving an exposed surface that then needs time for soil to regenerate to be productive once more (Sparling et al. 2003; Rosser \& Ross 2011; Heaphy et al. 2014).

Studies on a number of sites in New Zealand have measured the impacts of landslides on soil carbon (C), nitrogen $(\mathrm{N})$, Olsen $\mathrm{P}$, soil $\mathrm{pH}, \mathrm{CEC}$, bulk density, porosity, soil depth and pasture productivity through time. The findings often concluded that, following landslide events, soil $\mathrm{C}$ content increases over time, on average taking $\sim 60$ years to recover to $\sim 80 \%$ of total $\mathrm{C}$ in adjacent undisturbed areas (Lambert et al. 1984; Sparling et al. 2003; Rosser \& Ross 2011; De Rose 2013). Unlike soil C, the soil $\mathrm{pH}$ and total phosphorus $(\mathrm{P})$ changes over time were not associated with landslide age (Sparling et al. 2003). The C:N ratio recovered more quickly than physical soil properties when compared to non-slip sites (Sparling et al. 2003). The overall aim for this research was to improve understanding of soil recovery following landslides. The specific objectives were to:

- Identify and map landslides on the hill country and steeplands of Whatawhata Research Station, and to characterise selected landslides based on geomorphology, age, and soil characteristics

- Determine topsoil depth, colour, horizon development, and $\mathrm{C}, \mathrm{P}$, and $\mathrm{N}$ contents of four defined zones within each of the chosen landslides as well as a control zone for each site

- Develop a chronosequence of the soil properties using landslides of varying ages.

\section{Methods}

\section{Site description}

The Whatawhata Research Station is a sheep and beef farm situated about $20 \mathrm{~km}$ west of Hamilton, New Zealand. The soils on steeper hills are derived from Mesozoic siltstones, sandstones, argillite and greywacke (Kear \& Schofield 1964). Waingaro steepland soils (Mottled Yellow Ultic Soils) occur on steeper slopes $\left(30-40^{\circ}\right)$ and Kaawa hill soils (Mottled Yellow Ultic Soils) form on the moderate slopes (18$30^{\circ}$ ). The undulating to strongly rolling hills host tephra derived from the Mairoa and Hamilton ashes, forming Dunmore hill soils (Typic Orthic Allophanic Soils) (Bruce 1978). Elevation in the catchment ranges from about 60 to $375 \mathrm{~m}$ a.s.l. The mean annual temperature is $14.3{ }^{\circ} \mathrm{C}$ with a mean annual rainfall of $1607 \mathrm{~mm}$ (NIWA, 2015).

\section{Field methods}

Field surveying was conducted between December 2014 and May 2015. Landslides were initially located 
using aerial photographs (from AgResearch archives and Google Earth) to identify areas where probable landslide deposits and exposed soils were evident. The dates of landsliding were determined from the aerial photographs, creating a chronosequence of landslide events that dated from pre-1953 to 2014. The sites were visited for ground truthing and landslides were located using GPS. Following initial reconnaissance survey, 16 landslides were identified for further study. From the initial 16, six landslides were then chosen for detailed study and sampling, based on their morphology, dates of activation, and location (Table 1). Landslides 1-5 (LS1$5)$ were located within one paddock whilst Landslide 6 (LS6) was located on an adjacent ridge. Soils were investigated using a Dutch auger to determine soil horizonation and other profile characteristics.

Each landslide was divided into four zones (scarp zone, transitional zone, intact accumulation zone, and re-deposition zone, and an adjacent control zone). Zones were determined by visual assessment of geomorphic characteristics and physical position of the scarp zone (Figure 1). The scarp zone was characterised by near vertical faces with exposed saprolite and, at best, incipient shallow topsoils. The transitional zones consisted of 3-20 cm deep topsoils with small $<1 \mathrm{~m}$ diameter intact blocks ('floaters' of intact soil). Intact accumulation zones were areas of the landslide where large blocks ( $>2 \mathrm{~m}$ wide) of soil had remained intact although they had moved down-slope. The re-deposition zones were areas of re-deposited soil materials resting at the foot of the landslide. Re-deposition zones often had a shallow or non-existent A horizon overlying mixed soil materials. The control zones were located adjacent to, but outside, the landslide scar and represented the non-slipped landscape before failure.

\section{Soil sample collection methods}

Soil samples were collected in June 2015. Two bulked samples were collected from surficial materials in each zone of each landslide using a $3 \mathrm{~cm}$ diameter, $10 \mathrm{~cm}$ deep, core-sampler. Each sample consisted of 10 to 12 cores collected at the soil surface along a transect at about $1 \mathrm{~m}$ intervals in each of the five zones within each landslide area. The direction of sampling along each transect depended on the shape and size of the zone. The addition of samples from the control zones taken from side ridges adjacent to each slide gave a total of 60 samples. LS3 had only three of the zones (no intact accumulation zone was present) and so two extra samples were collected from the scarp and transitional zones.

\section{Laboratory methods}

Soil P, C and N, along with soil $\mathrm{pH}$ and moisture factors, were determined on $<2 \mathrm{~mm}$ air dried soil fractions. To measure plant available $\mathrm{P}$, the Olsen $\mathrm{P}$ method was used following Blakemore et al. (1987), but modified to increase soil from $1 \mathrm{~g}$ per $20 \mathrm{ml}$ of $\mathrm{NaHCO}_{3}$ reagent to $1.5 \mathrm{~g}$ and $30 \mathrm{ml}$ of the reagent. Total $\mathrm{C}$ and total $\mathrm{N}$ were determined on finely-ground soil samples using the dry combustion method in an Elementar-vario EL cube furnace. Soil $\mathrm{pH}$ was measured in distilled water

Table 1 Site locations and photo dates when landslides were evident.

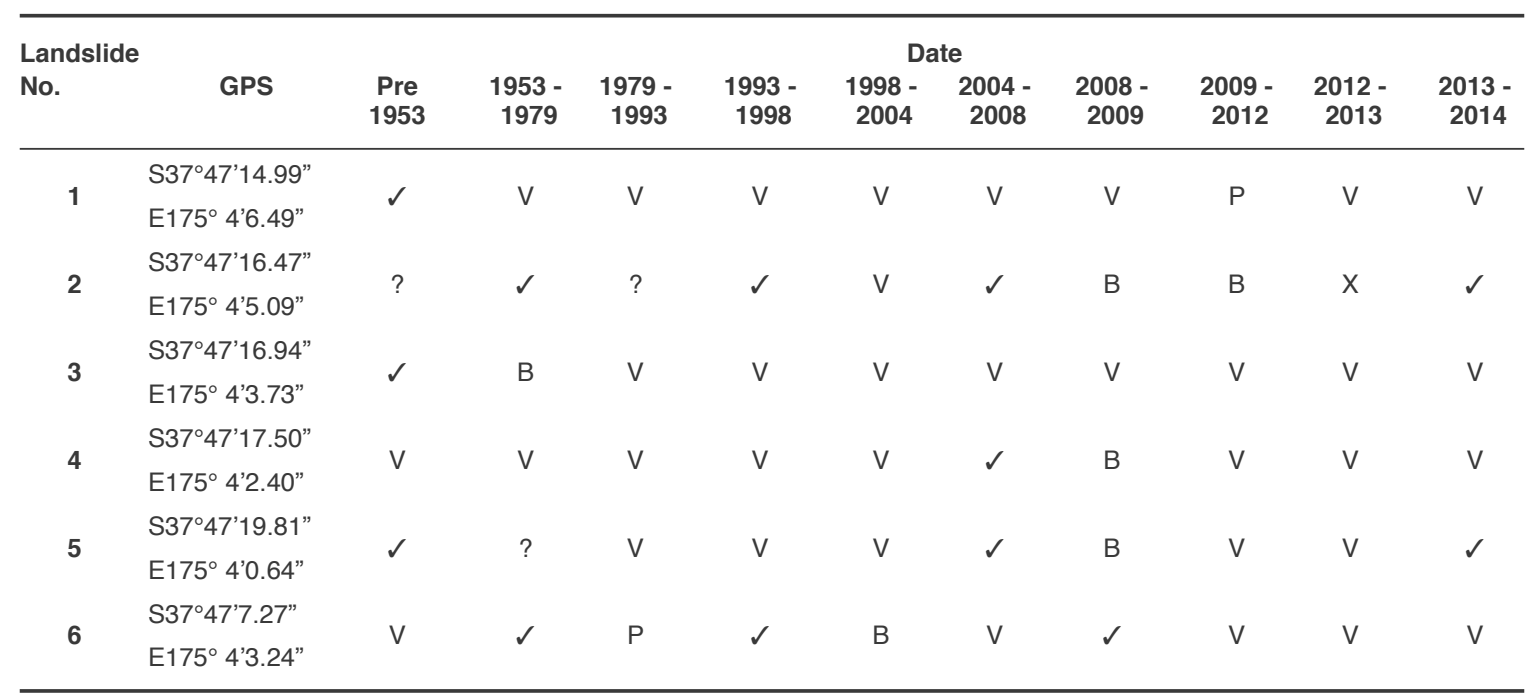




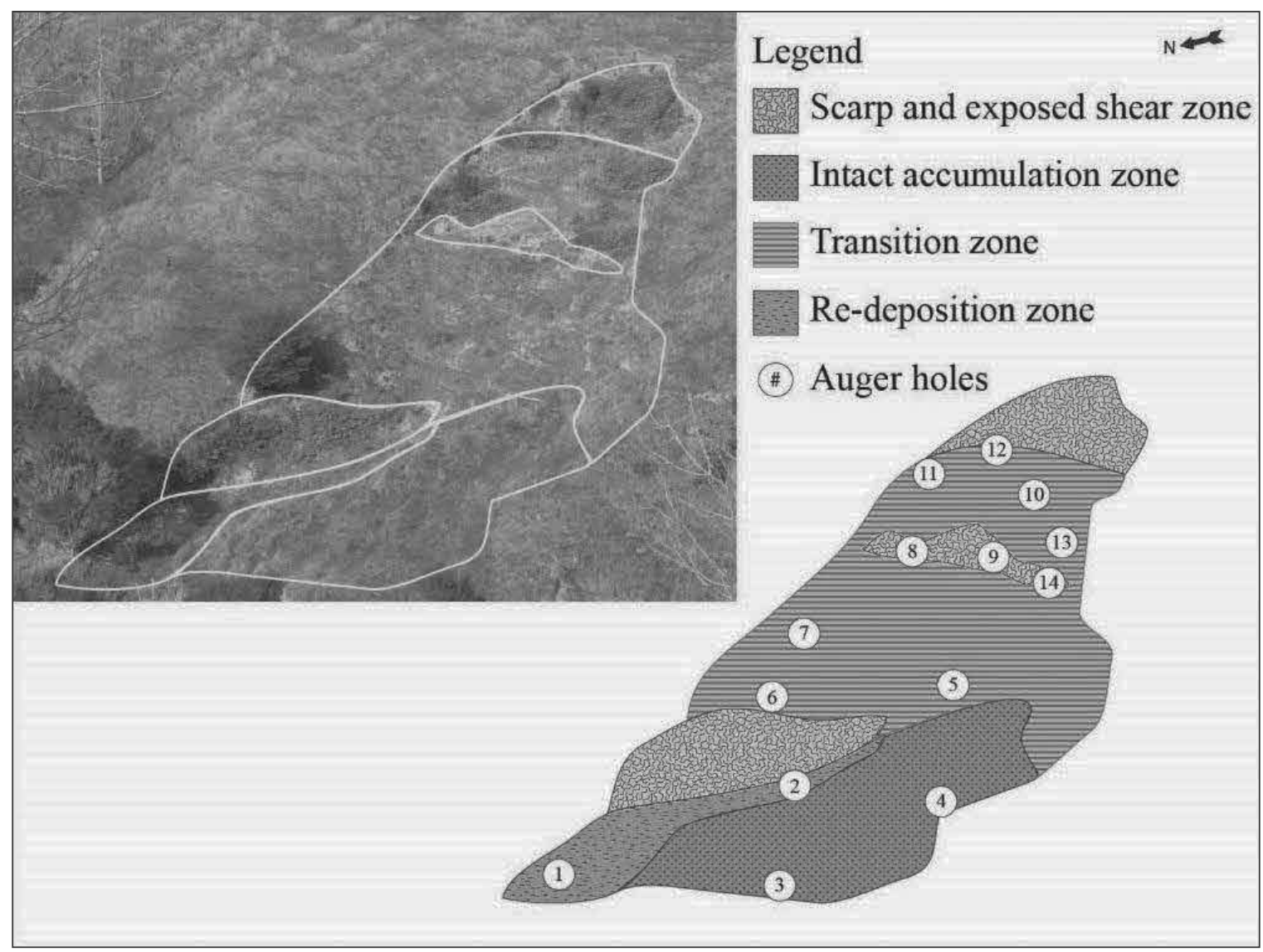

Figure 1 Example of landslide zones using schematic from

at a 1:2.5 soil-to-water ratio using a Janway glass electrode probe. Soil $\mathrm{C}, \mathrm{N}$, and $\mathrm{P}$ values were rated as high, medium, and low following the definitions of Blakemore et al. (1987).

\section{Results}

The largest portion of the landslides (about 40\%) comprised the transition zone (Figure 2). The shear zone equated to about $25 \%$ of the total landslide area.

A horizons were shallow and poorly developed in the shear and re-depositions zones, whereas the transition zones were variable depending on landslide age and floater distribution (Table 2). Intact accumulation zones were similar to control zones, but variable with some parts lacking soil between the intact blocks.

Soil $\mathrm{pH}$ ranged from 4.7 to 5.6 with no significant differences between landslides or zone, total $\mathrm{C}$ was low to medium (1-12) across the landslides, and total $\mathrm{N}$ was low to medium (0.1-1.0) (Table 3). The C:N ratio ranged from 11-16 across the landslides. Shear zones had the least soil recovery in terms of total $\mathrm{C}$ and $\mathrm{N}$. Soil $\mathrm{C}$ and $\mathrm{N}$ were lower $(\mathrm{P}<0.05)$ in each of the landslide zones compared to the control zones.

LS1 had unusually high Olsen P levels across all zones that were much higher than those expected in
Landslide 4, most recently activated in 2008 . Soil descriptions were conducted on auger samples for typical areas within each zone on each landslide. Soil properties, including soil horizonation, texture, and colour, were recorded to determine soil type and to characterise the varying zones in each landslide.

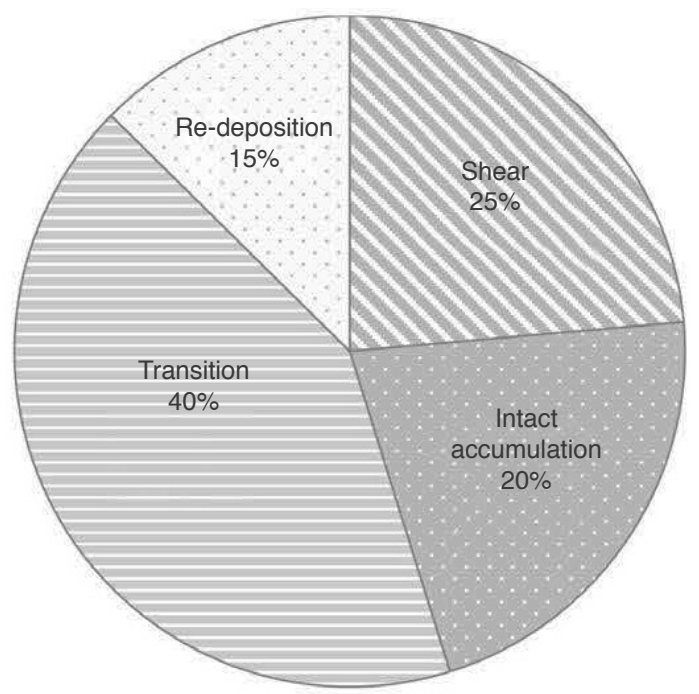

Figure 2 Mean area of each zone, as a proportion of total landslide area. 
Table 2 Soil depths, plant root depth, and A horizon colour for landslides at Whatawhata Hill Country Research Station.

\begin{tabular}{|c|c|c|c|c|c|c|}
\hline \multirow[t]{2}{*}{ Zone } & \multicolumn{2}{|c|}{$\begin{array}{l}\text { A horizon depth } \\
\text { (cm) }\end{array}$} & \multicolumn{2}{|c|}{$\begin{array}{l}\text { Solum depth } \\
\text { (cm) }\end{array}$} & \multirow[t]{2}{*}{ Typical A horizon colour } & \multirow[t]{2}{*}{$\begin{array}{l}\text { Root depth } \\
\text { (cm) }\end{array}$} \\
\hline & Mean & Range & Mean & Range & & \\
\hline Shear zone & 2 & $0-7$ & 24 & $0-100+$ & 10YR 4/6 brown & ND \\
\hline Intact accumulation zone & 17 & $5-25$ & 91 & $40-100+$ & 10YR $3 / 4$ dark brown & 53 \\
\hline Transition zone & 7 & $1-20$ & 72 & $17-100+$ & 10YR $4 / 3$ dull yellowish brown & 46 \\
\hline Re-deposition zone & 2 & $0-5$ & 90 & $50-100+$ & 10YR 3/4 dark brown & 26 \\
\hline Control & 20 & $15-30$ & $>100$ & $80-100+$ & 10YR 3/4 dark brown & ND \\
\hline
\end{tabular}

* ND $=$ Not determined

Table 3 Mean Olsen $\mathrm{P}$ and soil $\mathrm{pH}$ and soil Total $\mathrm{N}$, Total $\mathrm{C}, \mathrm{C}: \mathrm{N}$ ratio and proportions of $\mathrm{C}$ and $\mathrm{N}$ relative to controls for each zone in six landslides.

\begin{tabular}{|c|c|c|c|c|c|c|c|c|c|c|}
\hline \multirow[t]{2}{*}{ Landslide } & \multirow[t]{2}{*}{ Zone } & \multirow{2}{*}{$\begin{array}{c}\text { Proportion of } \\
\text { landslide } \\
\text { area } \\
\%\end{array}$} & \multicolumn{2}{|c|}{ Olsen $P^{2}$} & \multirow{2}{*}{$\begin{array}{c}\text { Soil } \\
\mathrm{pH}^{3}\end{array}$} & \multirow{2}{*}{$\begin{array}{c}\text { Total } \\
\mathbf{N}^{3} \\
\%\end{array}$} & \multirow{2}{*}{$\begin{array}{c}\text { Total } \\
\mathbf{C}^{3} \\
\%\end{array}$} & \multirow[t]{2}{*}{$\mathrm{C}: \mathrm{N}$} & \multirow{2}{*}{$\begin{array}{c}\text { Proportion } \\
\text { of } \mathrm{N} \text { to } \\
\text { control } \\
\%\end{array}$} & \multirow{2}{*}{$\begin{array}{c}\text { Proportion } \\
\text { of C to } \\
\text { control } \\
\%\end{array}$} \\
\hline & & & Mean & Std. Dev. & & & & & & \\
\hline 1 & Shear & 21 & 61 & 59.9 & 5.1 & 0.4 & 6 & 13 & 47 & 49 \\
\hline \multirow[t]{4}{*}{$\left(\right.$ pre-1953) ${ }^{1}$} & Intact accumulation & 15 & 126 & 4.1 & 5.1 & 0.6 & 7 & 12 & 63 & 59 \\
\hline & Transition & 55 & 105 & 5.8 & 5 & 0.5 & 6 & 12 & 55 & 54 \\
\hline & Re-deposition & 8 & 53 & 5.4 & 5.1 & 0.5 & 6 & 12 & 53 & 51 \\
\hline & Control & - & 18 & 9.9 & 5.2 & 1.0 & 12 & 12 & - & - \\
\hline 2 & Shear & 12 & 2 & 0.7 & 5.1 & 0.2 & 2 & 14 & 29 & 34 \\
\hline \multirow[t]{4}{*}{-2014} & Intact accumulation & 25 & 9 & 2.2 & 5.3 & 0.4 & 5 & 12 & 75 & 75 \\
\hline & Transition & 40 & 17 & 1.9 & 5 & 0.3 & 3 & 12 & 45 & 46 \\
\hline & Re-deposition & 23 & 4 & 1.9 & 5 & 0.2 & 2 & 12 & 29 & 30 \\
\hline & Control & - & 22 & 3.1 & 5.2 & 0.6 & 7 & 12 & - & - \\
\hline 3 & Shear & 50 & 8 & 12.6 & 5.3 & 0.3 & 4 & 12 & 56 & 55 \\
\hline \multirow[t]{3}{*}{ (pre-1953) } & Transition & - & 13 & 10.1 & 5.1 & 0.5 & 6 & 12 & 86 & 84 \\
\hline & Re-deposition & 39 & 10 & 9.3 & 5.3 & 0.3 & 4 & 11 & 55 & 51 \\
\hline & Control & 11 & 15 & 14.4 & 5.3 & 0.6 & 7 & 12 & - & - \\
\hline 4 & Shear & 20 & 1 & 1.2 & 5.1 & 0.1 & 1 & 12 & 8 & 8 \\
\hline \multirow[t]{4}{*}{-2008} & Intact accumulation & 24 & 10 & 4.7 & 5.2 & 0.4 & 4 & 13 & 52 & 53 \\
\hline & Transition & 47 & 5 & 1.2 & 5.2 & 0.2 & 3 & 13 & 35 & 36 \\
\hline & Re-deposition & 9 & 4 & 0.2 & 5.2 & 0.2 & 2 & 13 & 24 & 26 \\
\hline & Control & - & 15 & 4.9 & 5.2 & 0.7 & 8 & 12 & - & - \\
\hline 5 & Shear & 14 & 2 & 1 & 5.1 & 0.1 & 1 & 12 & 17 & 17 \\
\hline \multirow[t]{4}{*}{-2014} & Intact accumulation & 35 & 23 & 16.4 & 5.3 & 0.4 & 5 & 11 & 83 & 79 \\
\hline & Transition & 35 & 12 & 6.8 & 5.3 & 0.2 & 3 & 11 & 47 & 45 \\
\hline & Re-deposition & 15 & 6 & 2.1 & 5.2 & 0.1 & 2 & 13 & 28 & 31 \\
\hline & Control & - & 22 & 14.9 & 5.4 & 0.5 & 6 & 12 & - & - \\
\hline 6 & Shear & 29 & 1 & 1.1 & 5.4 & 0.1 & 2 & 14 & 15 & 18 \\
\hline \multirow[t]{4}{*}{-1995} & Intact accumulation & 22 & 10 & 1.5 & 5.5 & 0.5 & 5 & 12 & 60 & 63 \\
\hline & Transition & 44 & 11 & 2.5 & 4.8 & 0.3 & 4 & 14 & 36 & 44 \\
\hline & Re-deposition & 13 & 21 & 9 & 4.7 & 0.2 & 3 & 16 & 27 & 39 \\
\hline & Control & - & 40 & 28.7 & 5.6 & 0.8 & 9 & 11 & - & - \\
\hline
\end{tabular}

${ }^{1}$ Dates denote year of most recent landslide activation

${ }^{2}$ Mean of four replicates.

${ }^{3}$ Mean of two field replicates. 
hill country, thus they were omitted from subsequent statistical analysis. Olsen $\mathrm{P}$ was lower $(\mathrm{P}<0.05)$ than the control only in the shear and re-deposition zones.

\section{Discussion}

The shear zones were generally steep-faced exposed surfaces within the landslides comprising about $25 \%$ of the total landslide areas and were the slowest to recover. They had shallow A horizons (mean of $2 \mathrm{~cm}$ ), shallow (mean of $24 \mathrm{~cm}$ ) solum depths and low Olsen P values. The $\mathrm{C}$ and $\mathrm{N}$ were generally lower within the shear zone than other zones or the controls.

The intact accumulation zones made up about $20 \%$ of the landslide area. Intact accumulation zones had the deepest A horizons (mean of $17 \mathrm{~cm}$ ) within the landslides which was attributed to the soil moving down-slope in undisturbed blocks retaining the original topsoil. The mean soil $\mathrm{C}$ and $\mathrm{N}$ contents of the intact accumulation zones were higher than other landslide zones but lower than the controls. Olsen $\mathrm{P}$ values were variable but generally lower than the controls.

The transition zones (about $40 \%$ of landslide area) were a place of soil accumulation. They had thicker A horizons (mean of $7 \mathrm{~cm}$ ) and deeper solum depths (mean of $72 \mathrm{~cm}$ ) than shear zones therefore making them zones where soils will recover relatively quickly. $\mathrm{C}$ and $\mathrm{N}$ were medium to low with low Olsen $\mathrm{P}$ values.

The re-deposition zones (about 15\% of landslide area) had shallow A horizons (mean of $2 \mathrm{~cm}$ ) with the youngest landslides often having no, or minimal, topsoil. However, they are akin to the transition zone where soil accumulation occurs, with deeper solum depths and thus are likely to recover more quickly and be more productive than shear zones.

The soil recovery over time, as measured by $\mathrm{C}$ and $\mathrm{N}$ contents, was variable, with highest $\mathrm{C}$ and $\mathrm{N}$ in the pre1953 landslides and in the intact accumulation zones in all slides. The 1995-2014 landslides had the least recovery of soil $\mathrm{C}$ and $\mathrm{N}$ in the shear zones $(8-34 \%$ of control), and had only recovered to about $30 \%$ of the control values in the re-deposition zones. This finding is in general concurrence with Sparling et al. (2003) who reported that the $\mathrm{C}: \mathrm{N}$ ratio recovered to similar to controls within 5 years and that soil $\mathrm{C}$ had recovered to about $80 \%$ of adjacent non-eroded areas after 80 years.

The topsoil depths varied between zones but were generally within the range reported by Trustram \& De Rose (1988) though they didn't distinguish between the landslide zones they did recognise rafted material that would be equivalent to our intact accumulation and transition zones.

At similar sites, De Rose et al. (1995) reported that pasture production recovered fastest in the first 40 years after landslides and fully recovered after 80 years, while Rosser \& Ross (2011) suggest that most pasture productivity recovers in the first 20 years with only slow gains thereafter. This research suggests that in the intact accumulation, transition, and redeposition, zones pasture production will recover well within 20 years, however, the shear zones may take considerably longer to recover. Further work to measure pasture production within the varying zones of the landslide, along with management such as targeted fertiliser applications to maximise pasture recovery in the most responsive zones, could improve efficiency of management response following landslides.

\section{Conclusions}

Soil $\mathrm{C}$ and $\mathrm{N}$ were lower in each of the landslides zones than the control $(\mathrm{P}<0.05)$. Olsen $\mathrm{P}$ was lower $(\mathrm{P}<0.05)$ than the control only in the shear and re-deposition zones.

The differences in soil development, and in C, N, and $\mathrm{P}$, between zones within landslides were greater than the differences between landslides of varying ages. Shear zones take the longest to recover following landslides; they generally had the shallowest A horizons, shallowest depth of solum, and lowest C, N, and P levels, however, they occupied only about $25 \%$ of the landslide area. Intact accumulation zones are similar to control zones, but more variable as some with areas of exposed bare soil take longer to recover. The re-deposition and transition zones are areas where soil accumulates and, once stabilised, they are expected to be productive.

Plant-available $\mathrm{P}$ and soil $\mathrm{pH}$ were not correlated with soil development nor age of the landslides. Soil total $\mathrm{C}$ and $\mathrm{N}$ recovery were variable across the zones of the landslides with the oldest landslides and the soils in the intact accumulation zones having the highest contents of $\mathrm{C}$ and $\mathrm{N}$.

\section{ACKNOWLEDGEMENTS}

We thank Shane Hill, Mike Dodd, and Bill Carlson (AgResearch) for access to the study site and for aerial photographs and information regarding fertiliser trials. Sylvia Sabbagha, Paul Bayly, Justin Kelly, Kendell Noyes-White, and Holly Bredin-Grey are thanked for field assistance and Janine Ryburn for laboratory assistance. Thanks to the Broad Memorial Fund, Rick Noyes, and Janielle Wilson who provided funding support.

\section{REFERENCES}

Blakemore, L.; Searle, P.; Daly, B. 1987. Methods for chemical analysis of soils. New Zealand Soil Bureau Scientific Report 80: 103 pp.

Bruce, J. G. (1978). Soils of part Raglan County, South Auckland. Ed. Kinloch D. I. Wellington: New Zealand Soil Bureau Bulletin 41: 102 pp. 
Crozier, M.J. 2005. Multiple-occurrence regional landslide events in New Zealand: hazard management issues. Landslides 2: 247-256.

De Rose, R. C.; Trustrum, N. A.; Thomson, N. A.; Roberts, A. H. C. 1995. Effects of landslide erosion on Taranaki hill pasture production and composition. New Zealand Journal of Agricultural Research 38: 457-471.

De Rose, R.C. 2013. Slope control on the frequency distribution of shallow landslides and associated soil properties, North Island, New Zealand. Earth Surface Processes and Landforms 38: 356-371.

Heaphy, M.J.; Lowe, D.J.; Palmer, D.J.; Jones, H.S.; Gielen, G.J.H.P.; Oliver, G.R.; Pearce, S.H. 2014. Assessing drivers of plantation forest productivity on eroded and non-eroded soils in hilly land, eastern North Island, New Zealand. New Zealand Journal of Forestry Science 44: 24 (10 pp.)

Kear, D.; Schofield, J. C. 1964. Stratigraphic summary - Ngaruawahia Subdivision. New Zealand Journal of Geology and Geophysics 7: 982-983.

NIWA, 2015. The National Climate Database. Accessed 15/10/15. http://cliflo.niwa.co.nz/
Lambert, M. G.; Trustrum, N. A.; Costall, D. A. 1984. Effect of soil slip erosion on seasonally dry Wairarapa hill pastures. New Zealand Journal of Agricultural Research 27: 57-64.

Leathwick, J.; Wilson, G.; Rutledge, D.; Wardle, P.; Morgan, F.; Johnston, K.; McLeod, M.; Kirkpatrick, R. 2003-. Land environments of New Zealand. Ministry for the Environment/ Landcare Research, Wellington/Hamilton. 184 pp.

Rosser, B. J.; Ross, C. W. 2011. Recovery of pasture production and soil properties on soil slip scars in erodible siltstone hill country, Wairarapa, New Zealand. New Zealand Journal of Agricultural Research 54: 23-44.

Sparling, G.; Ross, D.; Trustrum, N.; Arnold, G; West, A.; Speir, T.; Schipper, L. 2003. Recovery of topsoil characteristics after landslip erosion in dry hill country of New Zealand, and a test of the space-fortime hypothesis. Soil Biology and Biochemistry 35: 1575-1586.

Trustrum, N. A.; De Rose, R. C. 1988. Soil depth - age relationship of landslides on deforested hillslopes, Taranaki, New Zealand. Geomorphology 1: 143-160. 